\title{
La narració de la Guerra Civil espanyola en els àlbums il·lustrats
}

\author{
Guida Planes Ferrer \\ Universitat Autònoma de Barcelona, Barcelona, Espanya
}

(Article rebut el 5 de maig de 2011; versió final rebuda el 9 de novembre de 2011)

En un moment en el qual la recuperació de la memòria històrica pel que fa a la Guerra Civil espanyola i a les seves conseqüències ha pres una nova embranzida tant en el debat públic com a nivell de les institucions, ens hem volgut plantejar com la literatura que adrecem als infants i als joves ajuda a transmetre aquests fets tan crucials i dramàtics de la història de l'Estat espanyol. La literatura pot tenir un paper important a l'hora de transmetre emocions que permetin als nens $\mathrm{i}$ als joves compartir i entendre el que va significar aquella guerra mitjançant les experiències i la memòria en primera persona dels personatges. Així serà possible que coneguin i es puguin apropiar d'aquesta part del passat, amb l'esperança que mai més no es puguin repetir uns fets com aquells.

L'objectiu d'aquest article és, d'una banda, exposar quin és l'estat actual de la publicació d'àlbums il·lustrats en llengües catalana i castellana que tracten el tema de la Guerra Civil espanyola (editats a partir de 1975, tant traduccions com obres de producció pròpia) i, de l'altra, analitzar quins són i com funcionen alguns dels elements particulars d'aquesta tipologia de llibres a l'hora de narrar els fets i les conseqüències d'aquesta guerra. Gràcies a la síntesi narrativa dels llenguatges del text i de la il·lustració, els àlbums il-lustrats s'erigeixen com un exponent de la comunicació de la postmodernitat, i, per tant, poden convertir-se en un mitjà especialment útil per transmetre fets i vivències als nens i als joves.

\section{Apropar la Guerra Civil espanyola als nens i als joves}

\author{
Si comprendre [el nazisme] és impossible, \\ conèixer és necessari, perquè el que va \\ succeir pot tornar. [...]Per això, meditar sobre \\ tot el que va passar és un deure de tothom. \\ Primo Levi, Si això és un home
}

Avui en dia, la literatura infantil i juvenil és transmissora d’informació i de missatges sobre els fets de la Guerra Civil espanyola en diversos gèneres i tipus de llibres, entre els quals el que volem estudiar aquí: l'àlbum il·lustrat. Pensem que pot ser interessant 
veure què ofereix aquesta tipologia de llibres, amb el seu doble llenguatge narratiu, a la comunicació d'uns fets històrics ja prou allunyats temporalment dels lectors.

Com es veurà a continuació, però, és especialment significatiu el nombre reduït d’àlbums il·lustrats localitzats que tracten aquest tema. Si després de gairebé quaranta anys de dictadura repressiva ja ha estat prou difícil que es generessin novel-les sobre la guerra en el cas de la narrativa per a adults, aquest tema encara ha costat més que fos tractat en la ficció de les obres adreçades als infants i als joves. Potser per un afany de protecció de cara als més petits, que s’han percebut com a vulnerables i s’ha cregut que temes dolorosos com les guerres o la mort no els pertocaven. O potser per la por de reobrir ferides del passat encara mal curades després de tants anys de silenci, amb el recel de despertar velles disputes o desconfiances (Portell, 2008: 58).

La cerca del corpus d'anàlisi s’ha fet a través de tres seleccions temàtiques de llibres publicades per tres entitats dedicades a l'estudi o la divulgació de la LIJ: La Guerra en la literatura para niños y jóvenes, de la Fundación Germán Sánchez Ruipérez de Salamanca, Il·lustrar i escriure la Guerra Civil, del Servei de Documentació de Literatura Infantil i Juvenil de Barcelona i Llibres de literatura infantil i juvenil i de coneixements que tracten de la guerra i la pau, del CRP SarriàSant Gervasi de Barcelona. A part dels àlbums localitzats en aquestes tres seleccions (Ferdindando el toro, El Moro, les taronges i la guerra, Fill de rojo, Els tres tambors, El barret del milicià, Guernica) se n'hi ha afegit un altre detectat aïlladament durant la cerca d'informació (Estos días azules...). El resultat ha estat de set àlbums il·lustrats, quatre que només estan publicats en català (tres dels quals pertanyen a una mateixa col·lecció), dos que només hi són en castellà, i un que té edició en les dues llengües.

Tal com diu Mata (2006), la literatura pot ser un instrument especialment vàlid per "fer Memòria”, perquè en les històries de ficció, històries personals, històries en minúscula, també s’hi pot rastrejar la Història en majúscula. Acostem-nos ara a aquestes històries en minúscula sobre la Guerra Civil espanyola, set àlbums il·lustrats.

\section{Una crida des del pacifisme}

D’entre tots aquests àlbums n'hi ha un que es diferencia de la resta per diversos factors, però sobretot perquè no parla explícitament de la guerra com ho fan els altres. Tot i estar ambientat explícitament a Espanya (a part del nom d'Espanya i de Madrid, hi apareixen molts símbols hispànics) i haver estat escrit el 1936 (i reeditat amb noves 
il·lustracions el 1984 en castellà per Lóguez, per això l'hem inclòs en l'anàlisi), aquest àlbum no narra pròpiament els fets de la Guerra Civil. Però sí que pot ser un molt bon punt de partida per parlar-ne i per analitzar diferents actituds davant d'un conflicte bèl·lic, per això no l'hem volgut obviar en aquesta selecció. Es tracta de Ferdinando el toro, ${ }^{1}$ amb text de Munro Leaf i amb il-lustracions i text manuscrit de Wernee Klemke. És un àlbum que va ser escrit i publicat inicialment als Estat Units el 1936, acabada d'esclatar la Guerra Civil espanyola. És l'expressió d'un autor estranger davant d'uns fets que considera reprovables i denunciables (l'esclat de la Guerra Civil espanyola), i vol ser un cant a la resistència pacífica, a la no-violència i a la llibertat personal per sobre de qualsevol doctrina, a través d'una història amb sentit de l'humor i de crítica social, protagonitzada pel toro Ferdinando.

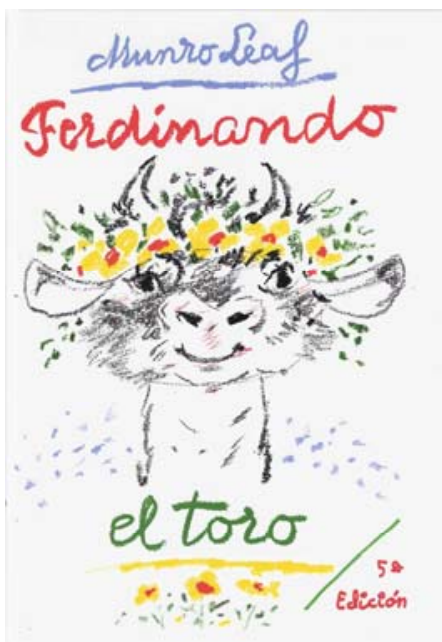

Fig. 1: Coberta de Ferdinando el toro

És un llibre singular, il·lustrat i manuscrit pel mateix artista, tot fet amb ceres de colors (amb negre i amb els colors primaris: verd, groc, vermell, blau), amb traços ràpids, que dóna un aspecte de frescor i de proximitat al dibuix infantil, malgrat que sovint és més complex del que pot semblar a primera vista i conté referències simbòliques dirigides a un lector més adult. Sobre paper de color blanc trencat, text i il-lustracions coloristes es combinen i comparteixen tot l'espai de cada doble pàgina sense cap esquema preestablert, fet que transmet una sensació d'espontaneïtat i de dinamisme. Són il·lustracions molt expressives, fins i tot caricaturesques, de manera que comuniquen de manera afectiva i enginyosa amb el lector. És destacable la funció de la tipografia manuscrita, on es juga especialment amb la mida de la lletra i amb els colors, segons la tensió del relat o el significat de paraules concretes. Text i il·lustració -i el color en tots 
dos llenguatges- participen en el joc narratiu per transmetre un missatge simbòlic ple de força i d'emoció.

\section{Valors positius en la rereguarda}

En el cas d'El Moro, les taronges i la guerra (1984), ${ }^{2}$ amb text de Ricard Creus i il·lustracions de Lluïsa Jover, ja hi apareix explícitament la guerra (fins i tot al títol), tot i que no es parla de quina en concret. Malgrat això, és recognoscible i identificable la Guerra Civil espanyola a través de les situacions que s’hi descriuen.

A més, hi ha elements paratextuals que contextualitzen la història, elements que cal tenir en compte en la narració quan es tracta d'àlbums il·lustrats. En un àlbum, cadascuna de les parts -portades, guardes, text, tipografia i imatges- formen part de la pròpia narració, i sovint esdevenen crucials per a la comprensió completa del llibre (Marantz, 2005). Per exemple, a la portadella interior hi apareix un subtítol que diu: “De quan jo era un nen": l'autor/narrador ens indica que es tracta d'una història que ell va viure quan era petit i, per tant, sabent que Ricard Creus va néixer el 1928 a Barcelona, és factible que ens parli en primera persona de les seves experiències com a nen durant la guerra. A part de contextualitzar, també és un detall que dóna veracitat al relat, ja que ens avança que d’alguna manera no és una història “inventada” sinó que qui ens l'explicarà en primera persona hi era, la va viure. És un fet força comú en la literatura que parla de la guerra que el propi autor hagi viscut aquesta experiència durant la infantesa i hi torni en els seus relats, convertits així en "testimonis literaris de gran força evocadora” (Polanco, 2000: 3).

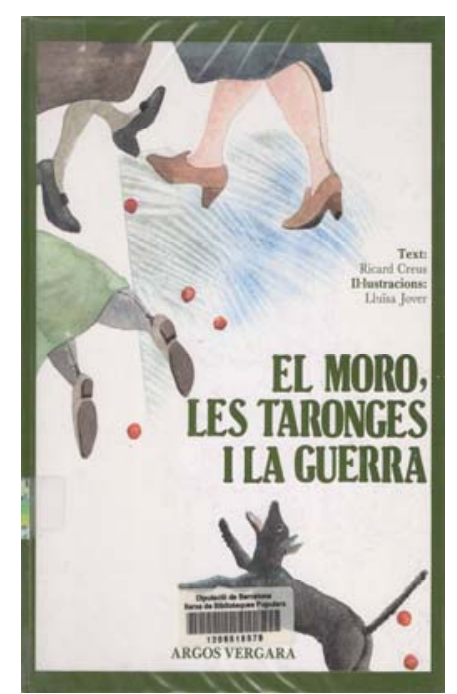

Fig. 2: Coberta d’El Moro, les taronges i la guerra 
La narració en primera persona i des del present, ens explica la història del nen a qui va tocar viure l'experiència de la guerra des de la rereguarda. Ens apropa a la vivència de la guerra des d'una òptica innocent, d'un testimoni involuntari. La guerra, però, és en aquest cas el rerefons per explicar-ne les conseqüències i els sentiments -positius i negatius- que despertava entre els qui la vivien. La narració està filtrada pels ulls d'un nen que vivia l'escassetat de menjar i per tant la gana, però també l'alegria i els jocs compartits amb els amics i la família, i les aventures de la seva colla amb el gos Moro.

El text va proporcionant pistes de la situació excepcional de guerra, però és sobretot a través de les il-lustracions que coneixem els detalls de la vida sota la presència de la guerra: les cares serioses dels adults, alguns d'ells escoltant les notícies de la ràdio (p. 11), les esquerdes en un vidre d'una finestra i a la paret, i també un llum de petroli, que fa suposar que hi havia talls d'electricitat o que no en tenien (p. 9) o els soldats armats que caminen rere la tanca del jardí (p. 13). Tot i això no hi ha una visió dramàtica ni especialment dura de la guerra, sinó més aviat una defensa dels valors positius també (o sobretot) en temps de guerra: la generositat, l'amor, l'afecte, l'alegria, la solidaritat.

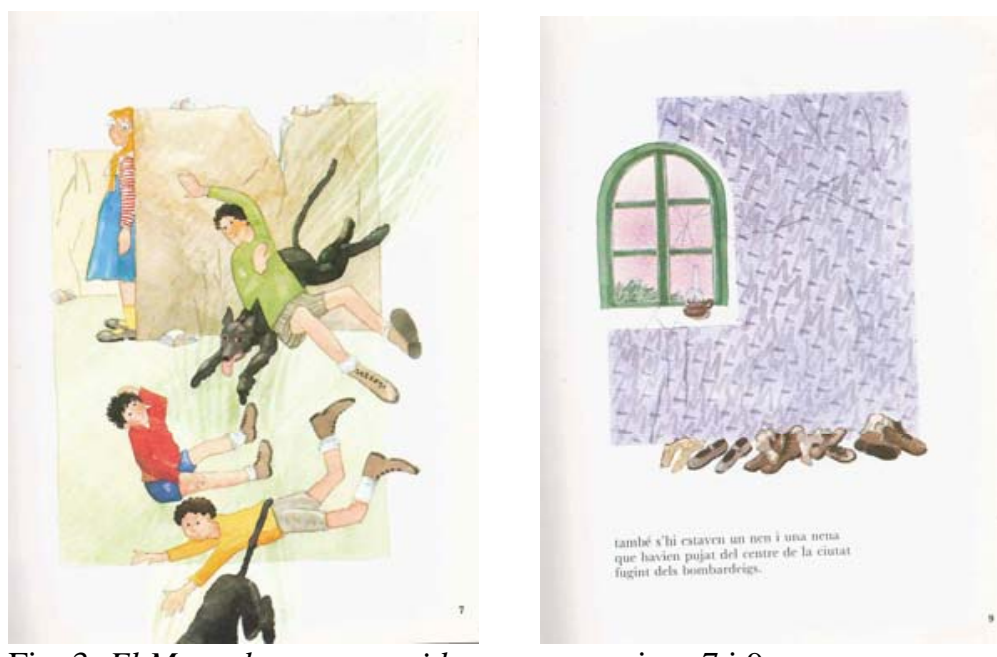

Fig. 3: El Moro, les taronges i la guerra, pagines 7 i 9

\section{La Guerra dels Grans}

L’any 2007, Tantàgora va inaugurar "La Guerra dels Grans”, una col·lecció d’àlbums il-lustrats formada actualment per tres títols: Els tres tambors (Roser Ros i Sílvia Cabestany), Fill de rojo (Joan Portell i Ignasi Blanch) i El barret del milicià (Laia Altarriba i Guillem Cifré). Com ja diu el seu nom, està explícitament dirigida a explicar 
aquesta "guerra dels grans” al públic infantil i juvenil, en aquest cas mitjançant unes històries basades en fets reals. Diu Juan Mata (2006) que

amb els "contes de veritat", diferents en personatges i escenaris als contes meravellosos, els nens i els joves aprenen a integrar en la seva biografia les experiències alienes, adquireixen un coneixement emocional del passat, estableixen els primers vincles amb els records dels seus ascendents. (p. 23)

Hi ha un primer element comú de la col·lecció que convé destacar per la informació que comunica: són els diversos elements paratextuals, com ara el text explicatiu de la contraportada o el de l'epíleg. Tots ells estan enfocats a donar veracitat als fets que es narren, a recalcar-ne la historicitat i a insistir en la desfeta que va comportar la guerra en general, però especialment per al bàndol republicà, el dels vençuts.

Però sobretot hi ha altres elements del llenguatge narratiu d'aquests àlbums il-lustrats que són especialment vàlids a l'hora de transmetre literàriament, i per tant també des del punt de vista emocional, aquests missatges anunciats pels paratextos. Un d’ells són les portades, en les quals tant els títols com les il·lustracions són molt expressius i serveixen per introduir el lector en un ambient que es percep trist, violent $\mathrm{i}$ fins i tot tràgic. Només amb les cobertes queda palès el pes narratiu que es dóna a la il-lustració i als elements com el color, el to o la perspectiva. I es reafirma que en l'àlbum il·lustrat, tal com diu Colomer (2002), la portada i la contraportada tenen sovint un paper narratiu que comença abans de llegir el text, en agafar el llibre i contemplar-lo com a objecte, o que acaba després de la lectura il·luminant retrospectivament el sentit de la història.

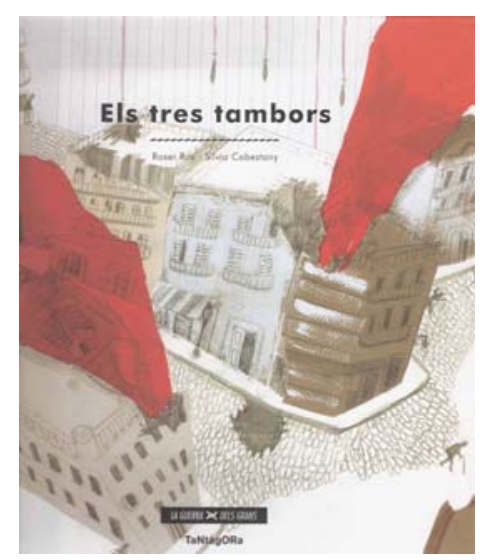

Fig. 4: Coberta d'Els tres tambors 


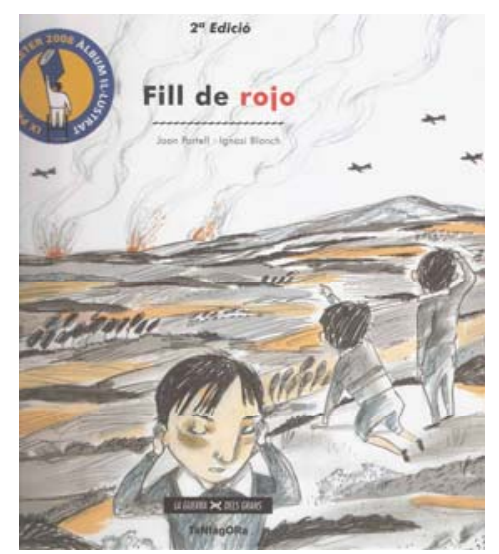

Fig. 5: Coberta de Fill de rojo

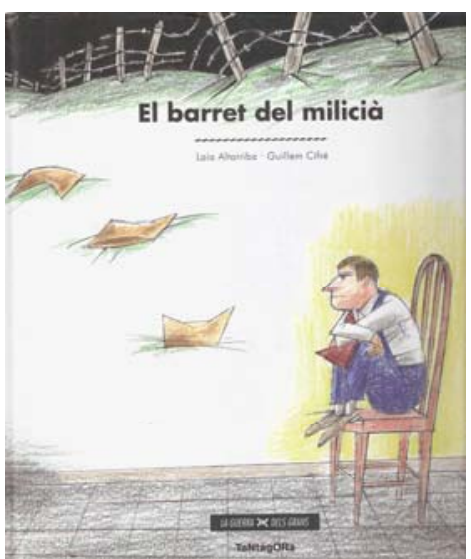

Fig. 6: Coberta d'El barret del milicià

És molt interessant també l'aportació narrativa de les guardes, que mostren una evolució entre les primeres i les finals i palesen els canvis traumàtics i les fractures produïts per la guerra. Especialment expressiu és el canvi en el model de l'escola republicana al de l'escola feixista, abans i després de la guerra, a les guardes de Fill de rojo. Canvis que, evidentment, comporten moltes més conseqüències i connotacions que les purament materials i que representen uns models contraposats de règim polític, de societat, d'educació, de valors...

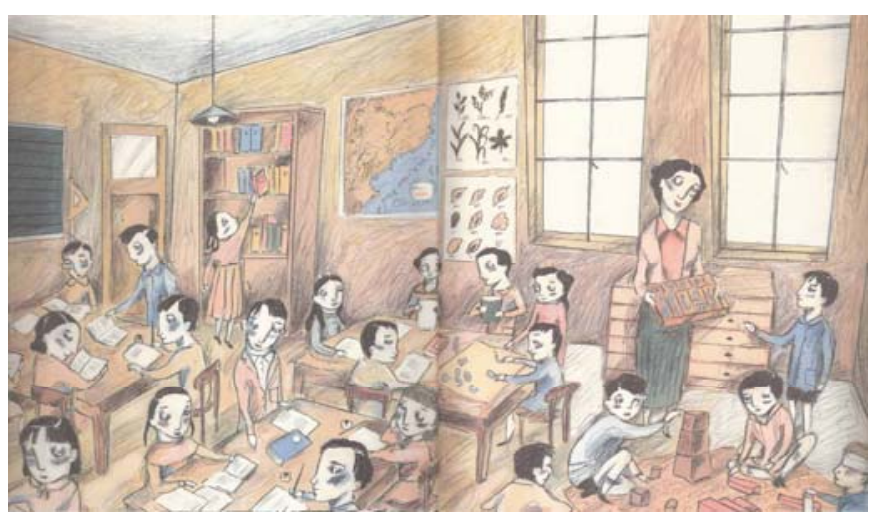

Fig. 7: Guardes inicials de Fill de rojo 


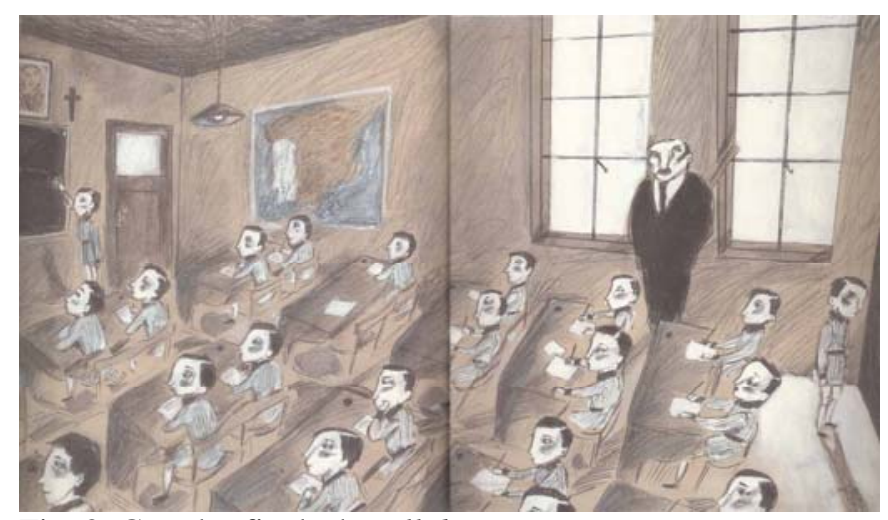

Fig. 8: Guardes finals de Fill de rojo

En tots tres àlbums es produeix un clar diàleg narratiu entre el text i la il·lustració, de manera que tots dos llenguatges aporten informacions vàlides i complementàries per al coneixement dels fets, i es dóna a la il-lustració un pes molt especial pel que fa a la comunicació de les vivències emocionals, tant a nivell simbòlic, com a través del traç, del to, dels colors, de la composició, etc. Les magníficament ben aconseguides escenes de destrucció, de la marxa cap a l'exili, de bombardeigs, etc. transmeten força i expressivitat, i involucren el lector en les experiències dures, i fins i tot aterridores, que viuen els personatges. ${ }^{3}$

En dos dels àlbums, la veu del narrador està posada directament en boca d'un nen, i en el tercer, en la d’un avi que retorna a la infantesa per explicar al seu nét les vivències de la guerra $\mathrm{i}$, per tant, també en aquest cas el narrador es col·loca finalment en la veu d'un nen. De nou és un narrador que des d'una òptica innocent viu uns fets que li resulten aliens i que descriu l'experiència a través del que observa dels adults, de les paraules, dels gestos. Aquesta veu narrativa infantil aporta més gravetat a la història: infància i guerra és un binomi especialment dolorós, perquè els nens són generalment víctimes destacades en tots els conflictes bèl-lics (Polanco, 2000).

\section{“Aquesta guerra la vam perdre tots”}

Amb aquesta frase acaba l'àlbum Estos días azules... (2009) -amb text d'Antonio Ventura i il-lustracions de Federico Delicado- i aquest vol ser el missatge clau d'aquesta història de ficció. De nou ens trobem davant d'un exercici de memòria històrica amb "l'esperança que el coneixement del dolor pot immunitzar contra la temptació de perpetuar-lo” (Mata, 2006: 25).

Aquí la història la protagonitzen avi i nét (com també hem pogut veure a Fill de rojo) i és a través d'aquest diàleg intergeneracional, amb la transmissió d'una història de 
persones normals i corrents, que el lector pot entrar en contacte amb la Història en majúscules.

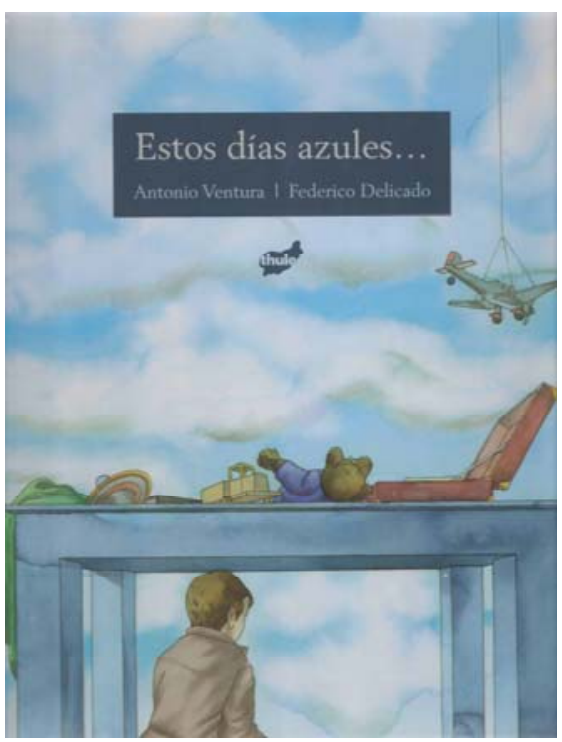

Fig. 9: Coberta d’Estos días azules...

Aquest àlbum va ser editat en el 70è aniversari de la mort d'Antonio Machado i el títol fa referència a uns versos famosos del poeta: "Estos días azules y / este sol de la infancia”, escrits complets a la portadella del llibre. Evidentment, només el lector adult podrà ajudar a interpretar aquestes informacions en acompanyar la lectura infantil de l'àlbum, informacions que aporten dades contextuals però que no són imprescindibles per a la comprensió de la narració. Tanmateix, el significat afegit en escollir aquests versos és clar, ja que Machado es va haver d'exiliar per la guerra i va morir just passada la frontera francesa.

Els diversos nivells de lectura, segons l'edat i els coneixements del lector, facilitats pel doble llenguatge narratiu de text i il·lustració, són una característica diferencial dels àlbums il-lustrats i permeten que lectors de diverses edats i amb experiències diferents es puguin apropiar de la narració i puguin accedir mitjançant diversos canals a una “comprensió perspícua del món” (Duran, 2007: 211).

El narrador és inicialment en tercera persona, fet que imposa una certa distància amb el lector. S'expressa en present $\mathrm{i}$ introdueix tres personatges, pertanyents a tres generacions: l'avi que ha viscut la guerra i que encara en sent el dolor, la mare que coneix la història però que no hi vol furgar per respecte a l'avi, i el nét, ignorant del passat, ingenu i inconscient, que demana a l'avi que torni a explicar "la història del camió”, com si fos un conte. La veu narrativa passa després en boca de l'avi que, a través del diàleg amb el nét, explica en primera persona i en passat els records de les 
vivències tràgiques de la guerra. No hi ha cap referència explícita en el text que situï el lector en una guerra concreta, però l'adult pot deduir de seguida de quina situació parla l'avi: la Guerra Civil espanyola, els bombardejos a la població i l'exili de ciutadans anònims cap a la frontera francesa. En aquest relat no hi ha cap judici moral fins al final de la història, quan l'avi ratifica al nen que els avions "eran malos”, però que aquella guerra no "la perdieron los malos" sinó que "la perdimos todos".

Les imatges són d'estil realista, un element que dóna veracitat i objectivitat al que s'explica. Això interessa als autors, que volen desfer la creença que la història del camió és un conte i recalcar els fets reals viscuts per l'avi. Un altre recurs destacable és que els dos temps de la narració, el passat i el present, estan representats de manera diferent en les il·lustracions. La narració en present, situada en una casa moderna actual, sempre està il·lustrada en color a pàgina dreta i a sang. Tot i el color, els escenaris són de tons suaus (cremes, marrons, grisos...), igual que el personatge de l'avi, que és mostrat com si d’alguna manera estigués “desgastat”, descolorit pel temps i la vida, amb posat trist. Contrasta amb els colors més vius de la roba de la mare i l'expressió alegre i el moviment del nen. En aquestes imatges del temps present, l'il·lustrador no busca tant l’impacte visual directe a través de contrastos forts o escenes punyents, sinó més aviat mitjançant detalls subtils, com ara expressions, gestos, objectes, o ombres, que ens aporten també informació narrativa.

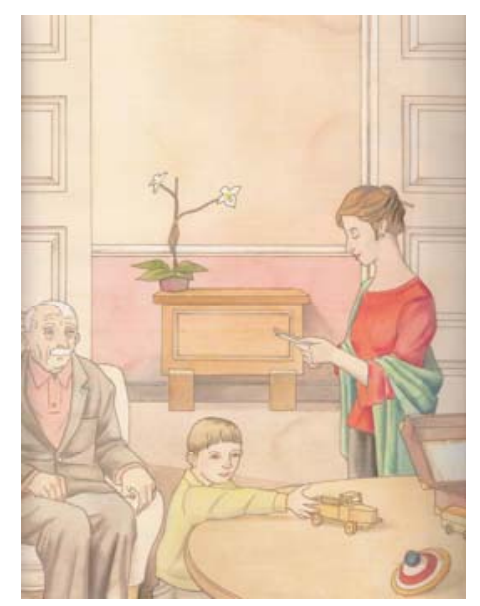

Fig. 10: Estos días azules..., pàgina 9 
La narració dels fets passats, en canvi, sempre s’il-lustra a pàgina esquerra, amb escala de grisos $\mathrm{i}$ amb un to sèpia com el de les fotos antigues. A vegades les imatges es presenten a sang i altres vegades focalitzades mitjançant un marc rodó al centre de la pàgina, com un zoom d'una càmera que escull destacar amb dramatisme uns elements significatius de l'escena i no uns altres. Són episodis de la fugida en camions cap a la frontera, que transmeten desolació, por, soledat. Per accentuar aquestes sensacions, l’il·lustrador s’ha servit també aquí de perspectives més forçades que en les imatges del present.

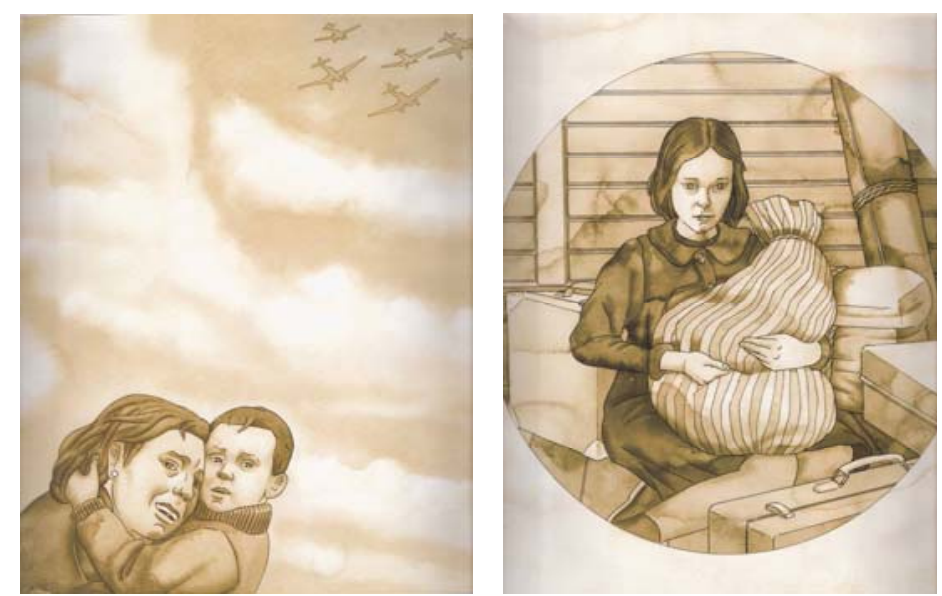

Fig. 11: Estos días azules... , pàgines 14 i 18

Enrere, tal com diuen les paraules de Machado, van quedar "Estos días azules y / este sol de la infancia”. Una mirada nostàlgica i adolorida, i una crida perquè se sàpiga que una guerra és sempre una pèrdua per a tothom.

\section{L'art i la barbàrie}

A Guernica (2008), amb text d'Heliane Bernard i il·lustracions d'Olivier Charpentier, l'eix central de la història és, tal com suggereix el títol, l’obra de Picasso que du el mateix nom. El narrador en tercera persona s'expressa com un cronista d'uns fets històrics: primer situa el lector en l'escenari de la Guerra Civil espanyola i del bombardeig de Guernica i de seguida focalitza la narració en un altre escenari paral-lel i contemporani a la guerra, la vida de Picasso. El lector te la sensació de sentir una veu en off que li narra el desenvolupament de l'acció en tots dos escenaris.

A banda del text de la història, també en aquest cas hi ha elements paratextuals que aporten informació complementària sobre el context històric i sobre la figura de Picasso i la seva obra i que exposen una clara voluntat de denúncia contra el feixisme i els qui hi van mostrar connivència. 
La "veu” de les il·lustracions és aquí especialment simbòlica, amb un estil pictòric fet de pinzellades i taques, jugant amb molt pocs colors: blau-gris, negre, vermell i el blanc trencat del paper. Són imatges molt punyents, que reforcen la sensació d'horror, de violència, de tristesa, de foscor, d'indignació. De vegades ocupen molt espai en la pàgina -fins i tot completament-, involucrant el lector en aquesta narració de l’horror i la barbàrie de Guernica. Altres vegades deixen espai blanc en la pàgina, mantenint més distància amb el lector i focalitzant allò amb què vol que ens fixem, 0 asserenant la narració quan es tracta d'escenes de la vida de Picasso, allunyades físicament de la violència de la guerra.

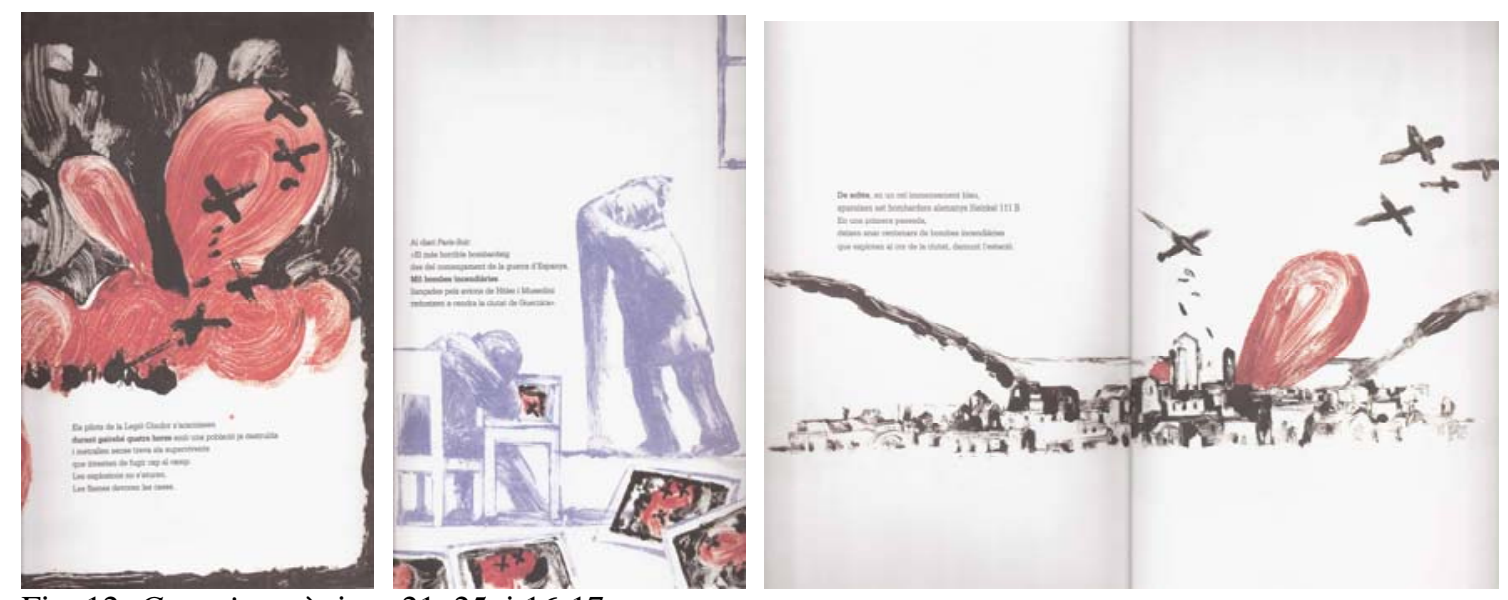

Fig. 12: Guernica, pàgines 21, 25, i 16-17

També la portada és impactant i fins i tot tètrica: fons negre, una taca de color blau-gris que forma una cara sense rostre (la de Picasso) i les lletres del títol a la part superior, amb una tipografia manual amb lletres majúscules irregulars que formen part del dibuix i amb un color vermell molt fort, com si fossin escrites amb sang.

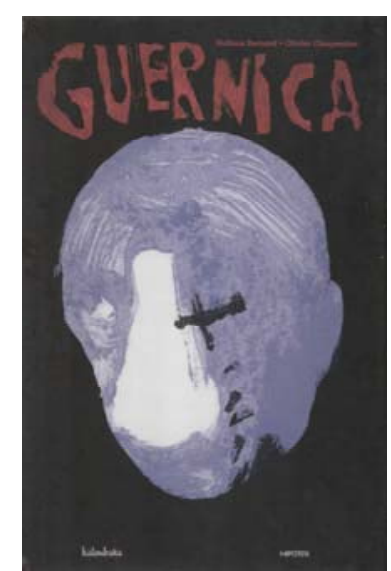

Fig. 13: Coberta de Guernica 
El pes narratiu de les il·lustracions, a través del to, de l'estil, de la composició, etc., es fa aquí molt palès, ja que transmeten informació de manera subtil i permeten experimentar al lector vivències emocionals i artístiques que s’afegeixen al coneixement dels fets transmès amb les paraules. Tal com diu Nodelman:

els diferents sentiments que les il-lustracions ens desperten respecte a una mateixa informació són una qüestió d'estil que involucra no només el que es dibuixa sinó també com ha estat dut a terme. L’estil és interpretació. (2005: 138)

La síntesi entre la veu textual, que vol semblar més objectiva i més distanciada -de cronista històric, tal com dèiem, malgrat la cruesa del que explica i la contundència amb què ho fa-, i les il-lustracions, amb un estil que busca l'impacte emotiu, es converteix per al lector en la possibilitat de viure una història amb un sentit final. Text i imatges es llegeixen junts com una història mútuament complementària (Moebius, 2005: 117).

\section{Els àlbums, una via d'implicació sensible}

Són set, doncs, els àlbums il·lustrats publicats en català i en castellà que, de manera diferent i des de diversos estils, narren o parlen de la Guerra Civil espanyola als nens i als joves. La majoria són històries individuals, retalls d'experiències de la infància i l'adolescència viscuda durant la guerra i la postguerra. Els protagonistes, nens i joves, acaben sent tan sols espectadors i víctimes d'una barbàrie i una tragèdia que no han buscat i que no entenen. Els ulls curiosos i sense malícia dels nens i les nenes de la guerra ens transmeten la por, la fam, la mort, la tristesa, la injustícia, però també les ganes de viure, de jugar, la solidaritat i la valentia. D’altres, com Ferdinando el toro, enfoquen la història des de l'òptica del pacifisme sense contextualitzar en la narració uns fets històrics concrets. I el Guernica, en canvi, explora un episodi concret i dramàtic de la guerra a través del sentiment i de l’obra de Picasso.

En l'època actual, en què el bombardeig constant d'imatges i d’informació arriba als nens $\mathrm{i}$ als joves de forma indiscriminada, es fa més necessari que mai el desenvolupament d'un sentit crític i d'una educació sensible als fets i a les persones, per tal de generar consciència i saber trobar les vies per no arribar a uns extrems tan dramàtics i desastrosos com els de la Guerra Civil espanyola. La guerra existeix a la televisió o als videojocs a través d'imatges cruels i impactants, amb efectes especials que fascinen grans i petits, on l'èpica de la lluita prima sobre el patiment i el dolor individuals i sobre els aspectes històrics que envolten els conflictes. D’alguna manera, tota aquesta allau «informativa» acaba tenint un efecte immunitzador i anestesiant sobre 
les persones, i més si estan en procés de formació de la personalitat com els infants i els joves.

Davant d'això, la literatura en general i concretament els àlbums il·lustrats poden ser una eina magnífica per entrar a poc a poc en la història de la Guerra Civil espanyola i per entendre'n les causes i conseqüències. Llegir -el text i les imatges- permet un espai per reflexionar, permet fer preguntes, permet sentir i empatitzar $-\mathrm{o}$ no- amb els personatges. Les propostes literàries d'aquests objectes de la postmodernitat (Duran, 2007), els àlbums, ens apropen al conflicte a través de la sensibilitat artística i emocional de tot el seu conjunt. Amb la doble capacitat narrativa del text i les il-lustracions, l'àlbum té l'oportunitat d'arribar a les persones d'una manera subtil, incisiva, poètica i, per tant, més directa a les emocions. Creiem que aquesta és una via especialment vàlida per implicar les persones més enllà del pur coneixement dels fets.

En el cas dels àlbums ressenyats, es fa palès l'objectiu que tenien alguns dels seus autors -i editors- de donar a conèixer uns fets concrets, de conservar i transmetre una part de la memòria històrica silenciada durant molt temps, de donar veu al bàndol dels vençuts. I sobretot la voluntat de donar espai als testimonis directes, ara que encara s’hi és a temps. La necessitat de relatar els fets des d'una òptica diferent de la dels vencedors -l’òptica convertida durant molts anys en única i obligatòria (Mata, 2006)ha estat encara relativament poc coberta per la literatura infantil catalana i castellana i encara menys si parlem d’àlbum il·lustrat. Per tant, és possible que sigui aquesta la raó per la qual diversos d'aquests àlbums dediquen força espai i recursos a contextualitzar, a comunicar dades i dates concretes, a situar el lector. En alguns casos això comporta una acumulació d'informació paratextual a nivell de contraportades, d'introduccions i epílegs, o un excés de zel informatiu en el text que provoca que la veu infantil del narrador sigui en alguns passatges menys creïble o expressi una càrrega ideològica de manera poc subtil.

Malgrat que aquest fet pugui restar qualitat literària en passatges concrets d'alguns dels àlbums, no hi ha dubte que aquests llibres poden ser un recurs literari i expressiu idoni per a la transmissió d’aquest passat tan important.

La sensació és que, quan s’hagi pogut explorar suficientment aquesta via de recuperació de la memòria històrica, es generarà espai per a la creació d'altres àlbums il-lustrats que prenguin com a escenari la Guerra Civil i les seves conseqüències sense la necessitat prioritària de donar tanta informació concreta dels fets. Val la pena oferir als 
petits i als joves l'oportunitat de conèixer d’on vénen, de viure i sentir amb els qui van patir situacions molt doloroses -perquè existeixen i són reals-, a través d'històries de ficció, de paraules i d'imatges que despertin la sensibilitat, les emocions i els facin créixer. Sobretot, sens dubte, amb l'objectiu que mai més no es tornin a repetir uns fets semblants.

\section{Referències bibliogràfiques}

Altarriba, L. (2008). Cifré, G. (il·l.). El barret del milicià. Barcelona: Tantàgora.

Bernard, H. (2008). Charpentier, O. (il·l.). Guernica. Traducció al català de J. Barahona. Barcelona: Hipòtesi-Kalandraka.

Colomer, T. (dir.) (2002). Siete llaves para valorar las historias infantiles. Salamanca: Fundación Germán Sánchez Ruipérez.

Creus, R., (1984). Jover, L. (il·l.). El Moro, les taronges i la guerra. Barcelona: Argos Vergara, Col·l. Els Llibres de la Gata, 5.

Duran, T. (2007). Álbums i altres lectures. Barcelona: Rosa Sensat.

Leaf, M., (1984). Klemke, W. (il·l). Ferdinando el toro. Santa Marta de Tormes: Lóguez.

Marantz, K. (2005). Con estas luces. A: El libro-álbum. Invención y evolución de un género para niños. Parapara Clave, núm. 1. Caracas (Veneçuela). Banco del Libro (2a ed.).

Mata, J. (2006). Hacer memoria. Travesías III. Cuadernos de Literatura Infantil y Juvenil,196: 22-31.

Moebius, W. (2005). Introducción a los códigos del libro-álbum. A: El libro-álbum. Invención y evolución de un género para niños. Parapara clave, núm. 1. Caracas: Banco del libro.

Nodelman, P. (2005). Pistas y secretos: cómo funcionan los libros-álbum. A: El libroálbum. Invención y evolución de un género para niños. Parapara Clave, núm. 1. Caracas: Banco del Libro (2a ed.).

Polanco, J-L. (2000). Ser niño en tiempos de guerra. Imaginaria, 22, Buenos Aires. Consultat l'abril de 2010 a www.Imaginaria.com.ar/02/2/guerra.htm. (Article publicat originalment a Peonza, núm. 50, p. 22-30, Santander: 1990.)

Portell Rifà, J. (2007). Blanch, I. (il·l.). Fill de rojo. Barcelona: Tantàgora.

Portell, J. (2008). Històries de la guerra “incivil”. A: Roig Rechou, B. A., Lucas Domínguez, P. i Soto López, I. (coord.) A Guerra Civil española na narrativa infantil e xuvenil (pp. 57-66). Vigo: Edicións Xerais de Galicia.

Ros, R. (2007). Cabestany, S. (il·l.), Els tres tambors. Barcelona: Tantàgora.

Ventura, A. (2009). Delicado, F. (il·l.), Estos días azules... Barcelona: Thule.

\section{Fonts per a la selecció del corpus d'anàlisi:}

-Il-lustrar i escriure la Guerra Civil. Guia de lectura desembre 2008, Servei de Documentació de Literatura Infantil i Juvenil, Biblioteca Xavier Benguerel de Barcelona. En línia: w3.bcn.es/fitxers/biblioteques/xbenguerel/sdlijguerracivil.065.pdf (consulta: gener 2010)

-La guerra en la literatura para niños y jóvenes. Fundación Germán Sánchez Ruipérez. Colección Temas en la Literatura Infantil y Juvenil, Salamanca 2003. Aquesta 
bibliografia va ser elaborada en motiu del III Congreso Internacional de la Asociación Nacional de Investigación de Literatura Infantil y Juvenil (Vigo, 3-5 de desembre de 2003).

En línia: http://www.fundaciongsr.es/pdfs/salamanca/Guerra\%20.pdf

(consulta: gener 2010)

-Llibres de literatura infantil i juvenil i de coneixements que tracten de la guerra i la pau. Recerca i selecció bibliogràfica a càrrec d'Alba Rebordosa. CRP Sarrià-Sant Gervasi, Consorci d’Educació de Barcelona, gener 2009. En línia:

http://blocs.xtec.cat/crpsarriasantgervasi/files/2009/01/literatura_guerra_i_pau.pdf

(consulta: gener 2010)

\footnotetext{
${ }^{1}$ L'edició original americana d'aquest llibre, amb el títol The story of Ferdinand i il·lustracions del propi autor, va ser escrita i publicada el 1936. L’edició inclosa en aquest estudi, però, correspon a la 2a versió del llibre, escrita a mà i il-lustrada per Werner Klemke, que en castellà va ser publicada el 1984 per l’editorial Lóguez i que s'ha reeditat en diverses ocasions (la consultada és la 5a edició, del 2003).

Sabem que n'existeix encara una altra versió titulada El cuento de Ferdinando, editada per Viking Penguin-Puffin Books, Nova York: 1990, amb il-lustracions de Robert Lawson i traducció de Pura Belpré, tot i que no l'hem poguda consultar.

${ }^{2}$ Malauradament descatalogat i avui en dia només localitzable en alguna biblioteca.

${ }^{3}$ Cal destacar que Els tres tambors va rebre el Premi Junceda 2008 d’il·lustració al millor Llibre infantil de ficció, concedit per l'Associació Professional d’Il·lustradors de Catalunya (APIC) i Fill de rojo, el IX Premi Llibreter 2008 d’Àlbum il·lustrat, concedit pel Gremi de Llibreters de Catalunya.
}

\section{Referència de l'autora:}

Guida Planes Ferrer és llicenciada en filologia francesa i romànica per la UAB i Màster en Llibres i Literatura Infantil i Juvenil per la UAB i el Banco del Libro de Venezuela. Ha treballat com a editora de literatura infantil i juvenil i com a coordinadora editorial de publicacions d'adults. Actualment treballa com a editora de llibres educatius de llengua catalana. També és correctora i assessora de dues revistes infantils en català (Cucafera i Tiroliro, de Bayard Edicions), i ha fet feines de correctora i traductora per a diverses editorials.

Correu electrònic: guidaplanes@hotmail.com

Agraïment: Aquest article és fruit del treball final del Màster en Llibres i Literatura Infantil i Juvenil organitzat per la UAB i el Banco del Libro de Venezuela. Vull agrair a la Teresa Colomer (directora), a la Marta Milian (tutora del treball), a les coordinadores i a tot el professorat la seva dedicació i la capacitat que han tingut per transmetre'm els coneixements i la passió pel món meravellós de la literatura infantil i juvenil (LIJ). 